\title{
Discours
}

Revue de linguistique, psycholinguistique et

informatique. A journal of linguistics, psycholinguistics

and computational linguistics

$7 \mid 2010$

Varia

\section{The Recategorization of the Rheme and the Structure of the Oral Paragraph in French and in Finnish}

\section{Mari Lehtinen}

\section{OpenEdition \\ Journals}

Electronic version

URL: http://journals.openedition.org/discours/8007

DOI: 10.4000/discours.8007

ISSN: 1963-1723

Publisher:

Laboratoire LATTICE, Presses universitaires de Caen

\section{Electronic reference}

Mari Lehtinen, « The Recategorization of the Rheme and the Structure of the Oral Paragraph in French and in Finnish », Discours [Online], 7 | 2010, Online since 20 December 2010, connection on 20 April 2019. URL : http://journals.openedition.org/discours/8007 ; DOI : 10.4000/discours.8007

\section{(c) $($ ) $\odot \odot$}

Discours est mis à disposition selon les termes de la licence Creative Commons Attribution - Pas d'Utilisation Commerciale - Pas de Modification 4.0 International. 

Revue de linguistique, psycholinguistique et informatique

The Recategorization of the Rheme and the Structure of the Oral Paragraph in French and in Finnish

Mari Lehtinen

University of Helsinki

Mari Lehtinen, «The Recategorization of the Rheme and the Structure of the Oral Paragraph in French and in Finnish», Discours, 7 | 2010, [En ligne], mis en ligne le 20 décembre 2010.

URL : http://discours.revues.org/8007. Consulté le 20 décembre 2010.

revues.org

CEATRE POURR LLÉDITION ÉEECTRONIQUE OUVER 



\title{
The Recategorization of the Rheme and the Structure of the Oral Paragraph in French and in Finnish
}

\author{
Mari Lehtinen \\ University of Helsinki
}

\begin{abstract}
At first sight, the intonation systems of French and Finnish - which are typologically distant languages - seem completely different. This paper aims, however, at showing that the discourse-structuring role of the utterance-final pitch rises in spontaneous spoken Finnish is in many respects reminiscent of the final pitch rises that constitute an essential component of the French intonation system (Morel \& Danon-Boileau, 1998). Indeed, in both cases, utterance-final pitch rises occurring inside a multi-unit turn seem to "recategorise the rheme as a preamble" for what will follow (Morel \& Danon-Boileau, 1998). 'Preamble' and 'rheme' are the two main constituents of the so-called 'oral paragraph', which is the basic structural unit of French discourse according to their model. In addition to comparing the realization of the so-called 'recategorization phenomenon' in French and in Finnish, this paper aims at describing the structure of the 'oral paragraph' of Finnish within Morel and Danon-Boileau's framework.
\end{abstract}

Keywords: oral paragraph, recategorization, rheme, intonation, pitch rise, Fo, spoken Finnish, Finnish intonation, prosody, structuration of discourse

À première vue, les systèmes intonatifs du français et du finnois - qui constituent deux langues typologiquement éloignées - semblent complètement différents. Le but de cet article consiste cependant à démontrer que les fonctions de la montée mélodique finale, qui constitue une composante essentielle du système intonatif du français (Morel et Danon-Boileau, 1998), sont à bien des égards similaires dans ces deux langues en ce qui concerne la structuration du discours oral spontané. En effet, dans les deux langues, une montée mélodique finale apparaissant à l'intérieur d'un tour de parole consistant en plusieurs unités semble servir - selon les mots de Morel et DanonBoileau (1998) - à «recatégoriser le rhème comme préambule » pour ce qui va suivre. "Préambule" et "rhème" sont les deux composantes principales du "paragraphe oral", qui est l'unité de base du français oral selon leur modèle. En plus de comparer la réalisation de ce "phénomène de recatégorisation" en français et en finnois, cet article a pour but de décrire la structure du "paragraphe oral" du finnois dans les termes du modèle français présenté par Morel et Danon-Boileau (1998).

Mots clés: paragraphe oral, recatégorisation, rhème, intonation, montée mélodique, Fo, finnois parlé, intonation du finnois, prosodie, structuration du discours

\section{Introduction}

When listening to oral discourse produced by native French speakers, one has constantly the impression of hearing large pitch rises at the end of utterances. This is not just an impression: indeed, utterance-final pitch rises constitute an essential component of the French intonation system (Delattre, 1966; Di Cristo, 1998; Fónagy, 1971; Fónagy \& Fónagy, 1983; Léon, 1992; Malmberg, 1976; Mertens, 1990; Morel \& Danon-Boileau, I998; Morel, 2003; Rossi, 198I, 1999; etc.). Finnish intonation, in turn, is characterised by a certain monotony due to its relatively small pitch intervals 
and a narrow variation range of pitch movements (Iivonen, 1998: 317; Hakulinen, 1979: 33; Iivonen et al., 1987: 236-239).

At first sight, the intonation systems of these two typologically distant languages seem completely different. The objective of this paper consists, however, in showing that there are some similar features as well. More precisely, this study aims at showing that the discourse-structuring role of the utterance-final pitch rises ${ }^{1}$ in spontaneous spoken Finnish is in many respects reminiscent of the final PR that constitute an essential component of the French intonation system (Morel \& Danon-Boileau, 1998). Indeed, in both cases, utterance-final PR occurring inside a multi-unit turn seem to "recategorise the rheme as a preamble" for what will follow (Morel \& Danon-Boileau, 1998: 9, 2I, 25, 6I).

'Preamble' and 'rheme' are the two main constituents of the so-called 'oral paragraph', which is the basic structural unit of French speech according to the model of Morel and Danon-Boileau (1998). The preamble always ends in a PR. It is a kind of introduction where the speaker expresses his point of departure and evaluates it (Morel \& Danon-Boileau, 1998: 37-44). The rheme, in turn, always expresses a singularized positioning of the speaker concerning the object of discourse that has been introduced in the preamble (Morel \& Danon-Boileau, 1998: 45-58); it constitutes, in a way, the "point" the speaker has been driving at in the preamble. The rheme is generally very brief, and its structure is of the type 'pronoun + verb $+X$ '. It basically ends in a pitch fall. However, a rheme can be "recategorised" as a preamble for what will follow with the help of an utterance-final PR. This recategorization phenomenon is an essential part of the French intonation system (Morel \& Danon-Boileau, 1998: 25 ), and it also constitutes the starting point for this contrastive study. In addition to comparing the realization of the recategorization phenomenon in French and in Finnish, this paper aims at describing the structure of the oral paragraph of Finnish in terms of the French model presented by Morel and Danon-Boileau (1998).

\section{Final pitch rises in French and in Finnish}

The most important conventional uses of utterance-final PR in French consist in indicating interrogativity and discursive continuity (Léon, 1992: I19-I40; Malmberg, 1976: 155-164; Morel \& Danon-Boileau, 1998: I5-16; etc.). The interrogative and continuative pitch patterns in French are strongly reminiscent of each other (Di Cristo, 1998: 202): what seems to distinguish an interrogative contour from a continuative one is the greater range (Rossi, 198I), steeper slope (Léon \& Bhatt, 1987), higher final pitch level (Boë \& Contini, 1975) and longer duration (Di Cristo, 1998; Wunderli, 1984) of the interrogative rise. Sometimes the interpretation of a rising contour as continuative or interrogative only depends on the communicative context (Di Cristo, 1998: 202). It has even been argued (Di Cristo, 1998: 202) that the interrogative pitch pattern is only a contextual variant of the continuative pitch pattern.

1. 'Pitch rise' will be shortened PR from now on. 
In their theory of French intonation, Morel and Danon-Boileau (1998: 9) claim that each prosodic parameter has its own iconic ${ }^{2}$ function in discourse. A PR, according to the authors (p. 13), originally indicated calling most of all; and the iconic uses of a rising pitch in discourse derive from this basic function. Calling the attention of the interlocutor and turning towards him can be mentioned among these iconic uses (pp. I2-16). A PR is used to focus the attention of the interlocutor on a certain 'theme'. It also refers to an assumed field of shared knowledge and invites the interlocutor to participate in the discussion. A rising pitch is a sign of an outward orientation of the speaker, whereas a falling pitch works in the opposite direction. According to Morel and Danon-Boileau (1998), PRs also have discourse-structuring functions in French: they contribute to distinguish small structural units inside larger entities. However, contrary to pauses (pp. I4-15), PRs connect, rather than separate, structural elements between which they occur. They constitute a kind of "thematic bridge" between the structural constituents within the boundaries of which they occur.

In Finnish, the declining basic pattern concerns both questions and statements (Iivonen, 1998: 317). Unlike in a number of other languages, in Finnish a final PR has not become a grammatical sign of interrogativity (Kallioinen, 1968; Hirvonen, 1970; Iivonen, 1978, 1998; Routarinne, 2003: 179-183). A rising pitch contour has traditionally been considered problematic in studies concerning Finnish intonation. According to the received view of Finnish intonation, final rises are rare and do not occur systematically (Iivonen, 1998, 200I). Still, utterances may also end with a rising pitch (Iivonen, 1978), and intonation contours occurring in spontaneous speech are, generally speaking, variable (Iivonen et al., 1987). Ogden and Routarinne (2005: 160) also point out that most studies concerning Finnish intonation are based on monologic or read data, and that final rises are actually common in spontaneous spoken Finnish.

Concerning the discursive functions of utterance-final PRs, Iivonen (1978) has stated that they often indicate thematic continuity in Finnish. The findings of Routarinne (2003) are similar. According to Routarinne (2003: 170), utterance-final PRs typically occur in narratives and imply that the narrator intends to continue speaking. This phenomenon creates expectations about the continuation of the line of narration, and it often occurs in utterances that guide the recipient towards the continuation of the story. A final PR also constitutes an interactional resource that calls for the reaction of the interlocutor (Routarinne, 2003: 170) and thus indicates that the speaker shows consideration for the interlocutor (p. I83). Indeed, Ogden and Routarinne (2005: 173) have shown that final rises in narratives "induce a minimal response from a coparticipant in which $\mathrm{she}^{3} \mathrm{can}$ mark herself as the recipient [...]".

2. The term 'iconic' is used by Morel and Danon-Boileau (1998) as opposed to 'conventional'. The 'iconic use' of a prosodic phenomenon is motivated by its acoustic shape, whereas a 'conventional use' is unmotivated; it is a social product created by the community of speakers of a language.

3. All participants of the data are female. 
Routarinne points out (2003: 169) that most (74\%) of the utterances marked by a final PR are declaratives or parts of them, and the marked utterances typically describe a state of affairs that is assumed to be shared knowledge. Utterance-final PRs typically occur in orientation sections in which the speaker describes the circumstances of the actual events of the story (Routarinne, 2003: 183-188) ${ }^{4}$. The PR indicates what the background information should be related to (Routarinne, 2003: 187). In other words, the PR projects the progression of a line of narration, a climax or some other continuation of the story for the understanding of which the information given in the marked utterance is particularly relevant.

Before Routarinne (2003), utterance-final PRs of Finnish have been systematically studied mainly in dialectal data. Wande (1982) has studied final PRs in the dialect of Tornionjokilaakso (Lapland), and Määtä (1973) in the dialect spoken in the region of Rovaniemi (Lapland). Both Wande and Määttä have treated final PRs as narrative devices. According to Määttä (1973), a final PR constitutes a means of appealing to the recipient, particularly typical of female guides. A rising intonation is also typically used in lists as an index of continuity (Lyytikäinen, 1995: 54-55).

\section{Data and methods}

The Finnish data presented in this paper is drawn from Routarinne (2003). The data consists of nineteen recordings including both face-to-face and telephone conversations between two participants. All speakers are 14-15-year-old Finnish schoolgirls living in Helsinki. The data has been recorded in I99I-I992 and in 1997. As the work of Routarinne (2003) is directed towards the role of parentheses and utterance-final PRs as narrator's interactional devices, it includes a lot of interesting examples of occurrences of utterance-final PRs in spontaneous Finnish speech. This was the main reason for choosing this data. The other reason is purely methodological: Routarinne's work falls within the framework of Conversation Analysis (CA), whereas this study aims at describing the same phenomenon from another methodological point of view. Using the same data facilitates the comparison. However, these data also have some disadvantages. For example, they have not been analysed acoustically in the same way as the French data ${ }^{5}$. The Finnish data are also much more limited than the French data both quantitatively and sociolinguistically.

The Finnish data will be compared to the theory on French intonation presented by Morel and Danon-Boileau (1998). This theory, called 'théorie de la coénonciation et de la colocution' ('theory of co-enunciation and co-locution'), provides detailed descriptions of the roles of different parameters of intonation, morphosyntactic features and lexical items in French speech. The data of the authors consist of over two hundred recordings that include very different speaking situations varying

4. The concept of 'orientation' is used here in the sense of Labov (1972).

5. A detailed phonetic study on the same data is however provided in Ogden and Routarinne (2005). 
from everyday and institutional conversations to text readings. The methodological approach and the main concepts of Morel and Danon-Boileau (1998) will be briefly presented in the following paragraphs and then illustrated with the help of an example in Section 4.

The basic structural unit in the theory of Morel and Danon-Boileau is the 'oral paragraph' which, in turn, has three main constituents: preamble, rheme and post-rheme. According to the authors (Morel \& Danon-Boileau, I998: 2I), the division into oral paragraphs is made mainly on the basis of suprasegmental features.

An oral paragraph usually ends in a pitch fall. The 'preamble' part, occurring at the beginning of a paragraph, always ends in a PR. One paragraph can include several (even ten) consecutive preamble segments. For this reason, French speech is characterised by long chains of PRs. These PRs ensure the internal cohesion of an oral paragraph (Morel \& Danon-Boileau, 1998). Concerning Finnish, this study suggests that the preamble segments do not normally carry a rising pitch; the cohesion of an oral paragraph is ensured by morphosyntactic features rather than by suprasegmental features. Only rheme segments that are "recategorised" as preambles for what will follow carry a final PR, for which reason utterances ending in rising pitch are less frequent than in French.

In French, the preamble is typically remarkably long and it has five constituents that always occur in a certain pre-established order: 'ligature', 'point of view', 'dissociated modus', 'framework' and 'disjointed lexical support'. Most often the preamble does not include all five above-mentioned constituents, but the authors point out (1998: 44) that if one (or several) of the constituents does (do) not occur, the functions it typically carries (they typically carry) are taken over by the other constituents. This paper suggests that the Finnish preamble is much more condensed than the French preamble. Whereas the French preamble constituents typically occur one after another, in the Finnish data, the preamble consists of overlapping segments.

The first element of the preamble is the 'ligature' (ligateur) that specifies the relationship between what has been said and what will follow. There are two kinds of ligatures: 'enunciative ligatures' and 'discursive ligatures'. Such expressions as $t u$ vois ('you see'), écoute ('listen'), bon ('well'), bab ('bah'), eb bien ('er well'), disons ('let's say') and en tout cas ('anyway') are examples of typical enunciative ligatures of French. Mais ('but'), et ('and'), donc ('so'), alors ('so', 'well') and parce que ('because'), in turn, are typical examples of discursive ligatures (Morel \& Danon-Boileau, 1998: 39).

The two following segments of the preamble specify certain modal aspects concerning the utterance they precede. These elements are called 'point of view' (point de vue) and 'dissociated modus' (modus dissocié) (Morel \& Danon-Boileau,

6. The English translations are only approximate: the uses of the translated expressions do not necessarily correspond to the uses of the original French expressions. 
1998: 40). The point of view emphasises the identity of the enunciator who is responsible for what is going to be said. The point of view is typically expressed by such elements as moi ('me'), à mon avis ('in my opinion'), pour moi ('in my view'), $X$ dit que... ('X says that'), selon $X$... ('according to $X$ '), etc. The dissociated modus, in turn, specifies the degree of certainty of the information that the speaker is preparing himself to deliver. Expressions typically occurring in this position are adverbs or verb constructions that have an epistemic or an evaluative value - for example effectivement ('indeed'), bien sûr ('of course'), peut-être ('maybe'), je crois ('I think'), j'ai l'impression ('I have the impression'), j'espère ('I hope'), etc.

In speech, the presentation of a thought proceeds step by step towards the contents that the speaker seeks to put into words (Morel \& Danon-Boileau, 1998: 37). This "approaching process" mainly happens inside the fourth preamble segment, called the 'framework' (cadre). The framework roughly indicates the field within which the contents of what is going to be said should be located. The framework typically consists of several sub-segments: the first sub-segment brings out a notion, and the second one specifies the predicative field of the notion that has been brought out in the first sub-segment. Finally, the third sub-segment (which is not a necessary one) can be used to present an element that will serve as the object for what will follow.

The last element of the preamble is the 'disjointed lexical support' (support lexical disjoint). This segment consists of a referential construction that later becomes an argument of the rheme. For this reason, the disjointed lexical support is always necessarily taken up by a personal, demonstrative or relative pronoun in the rheme. The element is intonatively and syntactically dissociated from the rheme. There are two types of syntactic constructions that can be used as disjointed lexical supports in French: I) the existential presentative structure il y a $Z^{7}$ ('there is Z'), and 2) a lexical support consisting in a pronominal replacement of the supporting element ( $\mathrm{Z}$ is taken up by a personal or a demonstrative pronoun in the rheme) (Morel \& Danon-Boileau, $1998: 38,4 \mathrm{I}-44)$. The preamble always ends in a rising pitch contour.

The preamble is followed by a rheme (Morel \& Danon-Boileau, I998: $45^{-58}$ ). Because of the recategorization phenomenon, there can be several (at least five) rhemes in a paragraph. The rheme always expresses a singularized positioning of the speaker concerning the object of discourse that has been introduced in the preamble. It is, however, not defined as the most informative constituent of a paragraph, or as the constituent carrying the "new information". The rheme is generally very brief, and its structure is of the type 'pronoun + verb $+X$ '. The pronoun can be a demonstrative, personal or relative pronoun. The ' $\mathrm{X}$ ' following the rheme is a complementary sequence the nature of which is variable: it can be a noun phrase, a verb phrase or an adverb. Most often the rheme starts with the presentative structure c'est ('it is'), but the rheme can also be constructed around a conjugated verb preceded by a subject pronoun and followed by a complementary sequence (also

7. ' $Z$ ' corresponds to an element acting as a disjointed lexical support. 
of variable nature). In some cases the rheme can also be built around an existential presentative structure. Often the rheme ends with a punctuating element (ponctuant) such as quoi ( 'I'm telling you'), bein ('eh') or voilà ( 'that's all').

The overall shape of the pitch curve during the production of the rheme is $\mathrm{L}-\mathrm{H}-\mathrm{L}$ (low - high - low). First, there is a PR carried by the constructing element of the rheme. Then, the pitch falls during the production of the penultimate syllable. The last syllable, in turn, can carry either a rising pitch or a falling pitch according to the status of the sequence with regard to what will follow: a falling pitch at the end of the rheme indicates finality and gives the sequence an independent position with regard to what will follow, whereas a rising pitch indicates continuity and recategorises the rheme as a preamble for what will follow. Thus, in one oral paragraph, there can finally be only one actual rheme: the one carrying a pitch fall. The recategorised rhemes that carry a PR are only "potential" rhemes; i. e. because of the final PR they lose their status of a rheme and become preambles. These "potential rhemes" can, however, be distinguished from other preambles by morphosyntactic and semantic criteria (as the rheme always expresses a singularized positioning). All PRs occurring inside the same oral paragraph also follow a line of declination (Morel \& Danon-Boileau, 1998: 25-26): a new constituent always ends in a lower pitch rise than the preceding constituent having the same function. For example, if the first preamble ends in a pitch rise reaching the level $\mathrm{H}_{4}$ (high), the second one typically ends on level $\mathrm{H}_{3}$ (mid-high) in the speaker's range ${ }^{8}$. When the line of declination is ruptured, a new oral paragraph starts.

Sometimes the rheme is followed by a final constituent of the oral paragraph, the so-called 'post-rheme' (postrbème, Morel \& Danon-Boileau, 1998: 28-32). Unlike the preamble and the rheme, the post-rheme is not a necessary constituent of the oral paragraph. The post-rheme consists of a group of syllables produced with a flat and low pitch on a decreased intensity level. The post-rheme never carries a final PR; it is always entirely produced with a flat pitch. Syntactically and semantically speaking the post-rheme can constitute either I) a sequence indicating epistemic modality or point of view (such as je crois, 'I think'; à mon avis, 'in my opinion', etc.), or 2) a nominal argument which is co-referent with a pronoun of the rheme. Other syntactic-semantic functions are not possible for this constituent.

\section{Example of the recategorization of the rheme in French}

The first example will illustrate the theory of Morel and Danon-Boileau (1998) concerning the structure of the oral paragraph and the recategorization of the rheme in spoken French (cf. Section 3). The example presents an extract drawn from a radio

8. Morel and Danon-Boileau (1998) use a relative scale varying from $\mathrm{H}_{\mathrm{r}}$ to $\mathrm{H}_{4}$ in order to describe the sizes of pitch movements. The level $\mathrm{H}_{\mathrm{I}}$ is the lowest level in the speaker's register and the level $\mathrm{H}_{4}$ is the highest level in the speaker's register. 
broadcast in which the participants talk about volunteers who will be working as teachers for long-term hospitalised children (Morel \& Danon-Boileau, 1998: 24). In this excerpt the host addresses one of his guests belonging to these volunteers ${ }^{9}$. A list of the conventions of transcription used here is given at the end of the paper ${ }^{10}$.

[I] oI quand vous dites vous êtes allé donner un cours $\left(\mathrm{H}_{4} / \mathrm{I}_{++}\right)$en fait $\left(\mathrm{H}_{3} / \mathrm{I}=\right)$ when you say you went to give a class in fact

$\mathrm{O} 2$ c'est e vous avez voulu $\left(\mathrm{H}_{3} / \mathrm{I}=\right)$ savoir comment on pouvait se it's er you wanted to know how one could

O3 rendre utile $\left(\mathrm{H}_{4} / \mathrm{I}-\right) \mathrm{pa}(\mathrm{r}) \mathrm{ce}$ que c'est vrai qu'souvent dans le ( $\left.\mathrm{H}_{\mathrm{I}} / \mathrm{I}-\right)$ make oneself useful because it's true that often in the

$04\left\{5_{0}\right\}$ dans not(re) courrier $\left(\mathrm{H}_{4} / \mathrm{I}-\right)$ on a des gens $\left(\mathrm{H}_{3} / \mathrm{I}-\right)$ qui disent $\left(\mathrm{H}_{2}+/ \mathrm{I}-\right)$ in our mail we bave people who say

o5 oh oui je $\{20\}$ suis à la retrai:te je ne $\{50\}$ sais pas quoi ob yes $I \quad$ am retired $I$ don't know what

o6 fai:re j'm'ennuie j'm'embête ${ }^{\circ}\left(\mathrm{H}_{4}{ }^{-} / \mathrm{I}=\right)\left\{_{3} \mathrm{O}\right\}$ et on peut très bien $\left(\mathrm{H}_{3} / \mathrm{I}-\right)$ to do I'm bored I'm fed up and one can very well

$07{ }^{\circ}$ vous n'êtes pas vous à la retraite ${ }^{\circ}\left(\mathrm{H}_{3}+/ \mathrm{I}=\right)\{60\}$ mais vous avez you are not retired yourself are you but you

o8 voulu $\left(\mathrm{H}_{4}-/ \mathrm{I}_{+}\right)$f/ $\{5 \mathrm{O}\}$ savoir comment on pouvait se rendre utile $\left(\mathrm{H}_{4} / \mathrm{I}=\right)$ wanted $f$ to know bow one could make oneself useful

o9 et $\{30\}$ et s'occuper $\left(\mathrm{H}_{4}-/ \mathrm{I}=\right)$ e: justement si on s'ennuie si on and and to get busy er indeed if one is bored if one

IO s'embête $\left(\mathrm{H}_{2}+/ \mathrm{I}-\right)$ y a plein $\left(\mathrm{H}_{4} / \mathrm{I}^{-}\right)$d'choses à faire $\left(\mathrm{H}_{4}-/ \mathrm{I}^{-}\right)$entre is fed up there are lots of things to do among

II autres $\left(\mathrm{H}_{4}-/ \mathrm{I}_{+}\right)\left\{5^{\circ}\right\}$ dans les hôpitaux $\left(\mathrm{H}_{4} / \mathrm{I}_{+}\right)$il y a des enfants $\left(\mathrm{H}_{3} / \mathrm{I}^{-}\right)$ others in hospitals there are children

I2 qui attendent des visites ( $\left.\mathrm{H}_{4} / \mathrm{I}-\right)\{60\}$ que ce soit d'ailleurs e who wait for visits it can be by the way er

I3 $\{40\}$ simplement pour leur apporter e : un peu d'tendresse $\left(\mathrm{H}_{4} / \mathrm{I}-\right)$ simply to provide them er: a little tenderness

I4 ou également $\left(\mathrm{H}_{3} / \mathrm{I}=\right)\{40\}$ pour e leur e donner quelques leçons dans as well as for er giving them some classes in

9. Both speakers are male. The ages of the speakers are not given.

10. The conventions of transcription correspond to those used by Morel and Danon-Boileau (I998). The English translations have been added. 
I5 différentes matières ( $\mathrm{HI}_{\mathrm{I}} / \mathrm{I}-$ ) alors effectivement comme

different subjects so indeed as

I6 le disait cet enfant $\left\{5_{5} 0\right\}$ Valérian $\left(\mathrm{H}_{4} / \mathrm{I}_{+}\right)\{30\}$

this child Valérian said

(Morel, Danon-Boileau, 1998: 24)

This extract includes three oral paragraphs which consist altogether of ten preambles and five rhemes. The first preamble is the sequence 'quand vous dites vous êtes allé donner un cours' ('when you say you went to give a class', line or). This preamble has two constituents: the 'point of view' and the 'framework'. The point of view ('quand vous dites', 'when you say') indicates the enunciator ('vous', 'you') of what will be said. The next constituent ('vous êtes allé donner un cours', 'you went to give a class'), in turn, constitutes a large framework for the topic that will be dealt with in what will follow. Like all the other preambles, this one carries a final $\mathrm{PR}\left(\mathrm{H}_{4}\right)^{11}$. It is also marked with a strong increase in intensity (I++). According to Morel and Danon-Boileau (1998: 18), a PR associated with an increase in intensity indicates focalisation: the PR points vocally at a certain fragment of speech, whereas the increase in intensity signals that the speaker intends to continue and does not want to be interrupted ${ }^{12}$.

The ligature 'en fait' (line or) constitutes the second preamble of the paragraph. Generally speaking, ligatures indicate the relationship between what has been said and what will follow. More precisely, 'en fait' ('in fact') is an enunciative ligature that directs the attention of the interlocutor towards what will follow. In other words, it constitutes a lexical means of emphasising the recategorization of the preceding unit (the first preamble) as a preamble for what will follow. Like the first preamble, the second one also ends in a $\mathrm{PR}\left(\mathrm{H}_{3}\right)$, which is, however, a bit smaller than the $\mathrm{PR}$ occurring at the end of the first preamble.

The second preamble ('en fait') is followed by the first rheme, 'c'est e vous avez voulu savoir comment on pouvait se rendre utile' ('it's er you wanted to know how one could make oneself useful', lines $\mathrm{O}_{2}-03$ ). The rheme starts here with the presentative 'c'est' ('it is'), which is, as already mentioned above (cf. Section 3), the most typical way to start a rheme. According to Morel and Danon-Boileau (1998: 46), when the rheme starts with the presentative ' $c$ 'est', the utterance is presented as a "pure rheme". The authors point out (p. 46) that the function of this type of structure is, however, to some extent paradoxical: on the one hand, it implies a consensus with regard to the object of the discourse, but on the other hand, the object is

11. $\mathrm{H}_{4}$ corresponds to the highest level of Fo movements in the system of Morel and Danon-Boileau (I998). According to the authors (p. I2), this level typically marks the end of a segment having the value of theme or of focalised constituent.

12. As this paper is focused on final PRs, changes of intensity associated to the pitch movements will not be systematically mentioned in the text below. Signs indicating the changes in intensity (I- / I = / I+ / I++) are, however, included in the transcription of example (I). 
identified by a differential property, in an egocentric manner. Thus, this type of structure provokes an interruption in the continuity of the discourse (Wagner, 1980: 92; Morel \& Danon-Boileau, 1998: 46). The rheme ends here in a PR $\left(\mathrm{H}_{4}\right)$, which is a bit higher than the final PR carried by the second preamble. According to Morel and Danon-Boileau (1998: 26), the fact that the final PR carried by the rheme is bigger than the one carried by the preceding unit (the second preamble) does not, however, interrupt the line of declination, because these two units do not have the same function (one of them is a preamble and the other one is a rheme). Instead, it unifies the whole constituted by the two preambles and the rheme and marks it as a preamble for what will follow. In the middle of the rheme sequence, there is a smaller PR $\left(\mathrm{H}_{3}\right)$ carried by the constructing element 'voulu' ('wanted', line 02$)$ of the rheme ${ }^{13}$.

After the rheme (recategorised as a preamble), there is again a new preamble sequence: 'pa(r)ce que c'est vrai qu'souvent dans le \{50\} dans not(re) courrier' ('because it's true that often in the in our mail', lines $\left.\mathrm{O}^{3}-04\right)$. This third preamble consists of four elements: ligature ('pa(r)ce que'), dissociated modus ('c'est vrai qu", 'it's true that') and two consecutive framework segments ('souvent dans le', 'often in the' and 'dans notre courrier', 'in our mail'), the first one of which is interrupted and followed by a 50-cs-long pause ${ }^{14}$. The discursive ligature 'parce que' ('because') indicates that the relationship between what has just been said and what will follow is explanatory in nature. The dissociated modus 'c'est vrai qu' ('it's true that') specifies the degree of certainty of the information that is going to be delivered: it indicates that the speaker is preparing himself to recall something that he considers to be an undeniable fact. Concerning the two framework segments, these elements delimit the predicative field projected by the preamble: the first, interrupted, framework segment 'souvent dans $l e$ ' ('often in the') brings out a temporal specification ('often' and not for example 'always' or 'sometimes'). The second framework segment 'dans notre courrier' ('in our mail'), in turn, presents the object of what is going to be said: it indicates that it is going to be the contents of the mail received by 'we' (represented singly by the speaker) that is going to be dealt with in what will follow. This third preamble ends in a PR $\left(\mathrm{H}_{4}\right)$ which is as high as the one occurring at the end of the first preamble sequence of the paragraph (line or) and the one produced at the end of the first rheme (line 03).

Before the second rheme, there is a fourth preamble sequence 'on a des gens' ('we have people', line 04). This element is a disjointed lexical support, which is, as already mentioned (cf. Section 3), the last constituent of the preamble. The disjointed lexical support is a referential construction that later becomes an argument of the rheme; for this reason, it is always taken up by a pronoun in the rheme. In this

13. As already mentioned above (cf. Section 3), the overall shape of the pitch curve during the production of the rheme is $\mathrm{L}-\mathrm{H}-\mathrm{L}$ (low - high - low). The high tone is carried by the supporting constructing element of which bears the rheme.

14. cs = centisecond. 
example, the element 'gens' ('people') introduced in the disjointed lexical support is immediately taken up by the relative pronoun 'qui' ('who') at the beginning of the rheme (line 04). This preamble sequence carries a final PR the size of which is - in accordance with the line of declination (cf. Section 3) - slightly inferior $\left(\mathrm{H}_{3}\right)$ to the PR produced at the end of the preceding preamble sequence.

The second rheme starts with the relative clause 'qui disent' ('who say', line 04) which refers to the element 'gens' ('people') introduced in the disjointed lexical support (line 04). The word 'disent' ('say' 's, line 04) constitutes the supporting element of the rheme; for this reason, it carries a final PR ( $\left.\mathrm{H}_{2+}\right)$. The relative clause is followed by an interpolated clause 'ob oui je \{20\} suis à la retrai:te je ne \{50\} sais pas quoi fai:re j'm'ennuie j'm'embête' ('oh yes I am retired I don't know what to do I'm bored I'm fed up', lines 05-06). The interpolated clause carries a final PR $\left(\mathrm{H}_{4}{ }^{-}\right)$which recategorises the rheme as a preamble for what will follow. When the structure of this rheme is transformed into that of a preamble, the relative clause ('qui disent', 'who say', line 04) becomes a point of view, and the interpolated clause (lines 05-06) becomes a framework constituent of the preamble.

The second rheme is followed by a new preamble, 'et on peut très bien' ('and one can very well', line 06 ), which is already the fifth preamble of the paragraph. This preamble consists of three elements: ligature ('et', 'and'), point of view ('on peut', 'one can') and dissociated modus ('très bien', 'very well'). According to Morel and Danon-Boileau (I998: II7), the ligature ' $e t$ ' indicates supposed consensuality between the participants about the object of discourse. It is often used to introduce a comment concerning the system of reference or the particular situation of the discourse. For this reason, this ligature frequently occurs at the beginning of an interpolated clause and - like in this particular case - immediately after an interpolated clause, when the main line of the discourse is taken over. As usual, this preamble also ends in a PR $\left(\mathrm{H}_{3}\right)$. It is immediately followed by an interpolated clause 'vous n'êtes pas vous à la retraite' ('you are not retired yourself are you', line o7), which ends in a PR of about the same size $\left(\mathrm{H}_{3+}\right)$.

The sixth preamble ends in a $\mathrm{PR}$ which is higher $\left(\mathrm{H}_{4}-\right)$ than the one occurring at the end of the preceding unit $\left(\mathrm{H}_{3}+\right)$. Thus, the line of declination is ruptured at this point. As already mentioned above (cf. Section 3), when the line of declination is ruptured, a new oral paragraph starts. In the new oral paragraph which is being started, the discourse is focused on the personal point of view of the guest who is being addressed. The sequence 'mais vous avez voulu' ('but you wanted', lines 07-08) that starts the new paragraph, consists of the same elements as the fifth preamble: ligature ('mais', 'but'), point of view and dissociated modus ('vous avez voulu', 'you wanted') ${ }^{16}$. Concerning the functions of the ligature 'mais', Morel and DanonBoileau (1998: II8) do not follow Ducrot's definition (1972: 27I) according to which

15. Third-person plural.

16. The same element, 'vous avez voulu', carries here both functions (point of view and dissociated modus). 
'mais' indicates argumentative inversion ${ }^{17}$. Instead, the authors argue that 'mais' constitutes a cooperative sign with the help of which the speaker maintains the object of discourse that has been preliminarily constructed and consensually shared, but he changes the angle from which this object is being dealt with (Morel \& Danon-Boileau, I998: II8).

The sequence 'savoir comment on pouvait se rendre utile et \{30\} et s'occuper e:' ('to know how one could make oneself useful and and to get busy er', lines 08-09) starting with the infinitive form 'savoir' ('to know') constitutes the third rheme of the extract (and the first rheme of the second paragraph). The word 'utile' ('useful') constitutes here the constructing element of the rheme; it carries a strong final PR $\left(\mathrm{H}_{4}\right)$. The word 's'occuper' ('to get busy'), which is the last word of the rheme, also carries a final $\mathrm{PR}\left(\mathrm{H}_{4}-\right)$. Consequently, the rheme is, once again, recategorised as a preamble for what will follow. These two strong PRs also mark an interruption of the line of declination with regard to the interpolated clause 'vous n'êtes pas vous $\grave{a}$ la retraite' ('you are not retired yourself are you', line 07), which is the last element of the preceding paragraph.

The third rheme is followed by the seventh preamble, 'justement si on s'ennuie si on s'embête' ('indeed if one is bored if one is fed up', lines o9-1o). This preamble consists of the word 'justement' ('indeed', line o9) acting here both as the ligature and as the dissociated modus, and of the sequence 'si on s'ennuie si on s'embête' ('if one is bored if one is fed up', lines o9-Io) which makes up the framework. The preamble carries a relatively low final PR $\left(\mathrm{H}_{2+}\right)$. It is immediately followed by the fourth rheme of the extract, ' $y$ a plein d' choses à faire' ('there are lots of things to do', line Io) starting with the existential presentative structure '[il] y $a$ ' ('there are'). According to Morel and Danon-Boileau (1998: 140), this type of depersonalised structure presents the information given in the rheme as being associated with an external point of reference. In this case, it presents the rheme as a general description of the prevailing circumstances. As usual, this rheme also carries two PRs: the first one $\left(\mathrm{H}_{4}\right)$ occurs at the end of the constructing element 'plein' ('lots of), and the second one $\left(\mathrm{H}_{4}-\right)$ at the end of the last word ('faire', 'to do') of the rheme. Thus, as this rheme, too, ends in a PR (instead of a pitch fall), it is recategorised as a preamble for what will follow.

There are still two more preambles before the fifth rheme, which is the last one of the excerpt presented in Example [I]. The eighth preamble, 'entre autres $\{50\}$ dans les hôpitaux' ('among others in hospitals', lines IO-II), consists of a ligature ('entre autres', 'among others') and of a framework ('dans les hôpitaux', 'in hospitals'). Both constituents carry a final $\mathrm{PR}\left(\mathrm{H}_{4}-\right.$ and $\left.\mathrm{H}_{4}\right)$, and there is a 50-cs-long pause between them. As the size of the final PR produced at the end of the eighth preamble is

17. Remarks presented by e. g. Riegel, Pellat and Rioul (1994: 619-620) and by Grevisse and Goosse (2008: 1399) about the role of 'mais' as an element of opposition are similar to those presented by Ducrot (I972: 27I). 
superior $\left(\mathrm{H}_{4}\right)$ to the final $\mathrm{PR}\left(\mathrm{H}_{2}+\right)$ produced at the end of the seventh preamble, the line of declination is ruptured here. Thus, the eighth preamble starts a new oral paragraph. In the new paragraph, the speaker goes back to the main topic of the discourse, "children in hospital".

The ninth preamble is the existential presentative structure 'il $y$ a des enfants' ('there are children', line II), which is a typical disjointed lexical support of the type [il y a Z] (Morel \& Danon-Boileau, I998: 4I-42). According to the authors (pp. $4 \mathrm{I}^{-42}$ ), in such cases the supporting element $[Z]$ is associated with a large paradigmatic class of potential predications. The predicates that are actualized in the following rheme will define the characteristics of the supporting element ${ }^{18}$.

The supporting element 'enfants' ('children', line II) is taken up by the relative pronoun 'qui' ('who', line I2) at the beginning of the fifth rheme, 'qui attendent des visites $\{60\}$ que ce soit d'ailleurs \{ 40$\}$ simplement pour leur apporter e: un peu d' tendresse ou également $\{40\}$ pour e leur e donner quelques leçons dans différentes matières' ('who wait for visits it can be by the way er simply to provide them er: a little tenderness as well as for er giving them some classes in different subjects', lines I2-15). Contrary to all preceding rhemes, this one ends in a pitch fall instead of a PR. Thus, unlike the preceding rhemes, the fifth rheme is not recategorised as a preamble, but keeps the status of a rheme and marks, finally, the end of the oral paragraph (consisting of three sub-paragraphs linked up by the recategorization phenomenon) ${ }^{19}$.

The last sequence of the extract, 'alors effectivement comme le disait cet enfant \{50\} Valérian \{30\}' ('so indeed as this child Valérian said', lines I5-16), constitutes the first preamble of the next oral paragraph, in which the speaker starts talking of the topic from another perspective (i.e. from the perspective of a hospitalised child to whom the guest of the broadcast had paid a visit) (Morel \& Danon-Boileau, 1998: 25).

\section{Recategorization of the rheme and the structure of the oral paragraph in teenage Finnish girls' conversations}

Example [2] below illustrates the realization of the recategorization phenomenon in Finnish. The extract has been drawn from a telephone conversation presented by Routarinne (2003: 184$)^{20}$.

18. As already mentioned above (cf. Section 3), the disjointed lexical support is always necessarily the last preamble constituent before the rheme.

19. The pitch fall is associated with decreased intensity (I-) and with non-lengthened duration $(\mathrm{D}=)$. According to Morel and Danon-Boileau (1998: 25), it is the accumulation of these three suprasegmental features (and not the pitch fall alone) that indicate unambiguously the end of an oral paragraph.

20. The English translations have been added. The transcription conventions used by Routarinne (2003) correspond to those generally used within CA; a list of these conventions is given at the end of this paper. Pitch curves and other phonetic analyses of the same data are provided in Ogden and Routarinne (2005). 


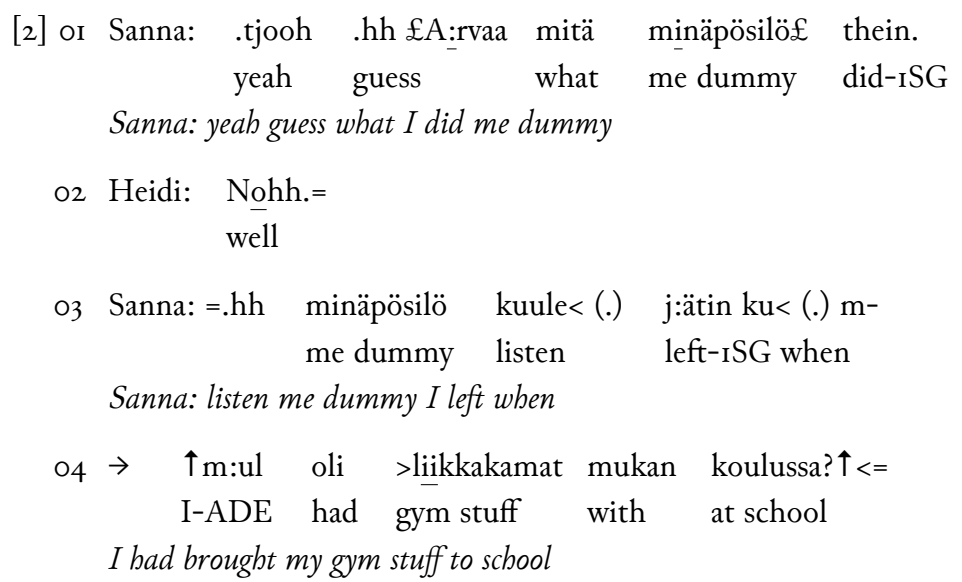

o5 Heidi: =mm=

PRT

o6 Sanna: =sit mul oli< $\downarrow$ siin Afrikkakaupan kassis Then I-ADE had that-INE African shop-INE bag-INE Sanna: then I bad in this bag I found in an African shop

o7 $\downarrow=$ Mul oli siel sit kaikki.hhh mun dö $\uparrow$ dö: I-ADE had there PRT everything my deodorant I had everything there my deodorant

o8 ha:rja meikkipussi, .hh ja sitteh< .hh >£Näist brush toilet bag and then these-ELA brush toilet bag and then these

o9 Kaapeist ei oo mitää m:uut har: $<$ (.) haittaa, cupboards NEG is anything but ha: harm cupboards cause notbing but harm

IO m(h)ä j(h)ätin:£ .mt kaappii I left-ISG cupboard-IL I left that bag in the cupboard

II siel $\uparrow$ on nyt kaikki there are now all my deodorants and make-ups and (Routarinne, 2003: I84) (5.9) [koulu.pub 'school.tel'] MINÄPÖSILÖ 'me dummy'

This extract includes two oral paragraphs. The first one starts with the preamble 'tjoob .hb a:rvaa mitä minäpösilö' ('yeah guess what I did me dummy', line or). The preamble starts with the enunciative ligature 'tjoob' ('yeah'), which is followed by the framework segment 'a:rvaa mitä minäpösilö thein' ('guess what I did me dummy'). In this segment the speaker gives the interlocutor a rough idea of what she intends to say: she is going to describe something that she has recently done. In 
addition to indicating the field for what is going to follow, this preamble segment also includes an element that carries an obvious modal implication: the compound 'minäpösilö ('me dummy', line or). This element constitutes the dissociated modus of the preamble.

The interlocutor ('Heidi') marks the reception of the turn with the enunciative particle 'nobb' ('well', line o2), after which the first speaker ('Sanna') continues telling her story (line 03). This second preamble ('minäpösilö kuule jätin ku', 'listen me dummy I left when') starts with the compound 'minäpösilö ('me dummy') which was already introduced in the first preamble. Here too, 'minäpösilö' constitutes the dissociated modus of the preamble. After this element there is an enunciative ligature, 'kuule' ('listen'), which, in turn, is followed by the framework segment ' $j a ̈ t i n ~ k u$ ' ('I left when'). As the ligature 'kuule' occurs here after the dissociated modus, the order of the preamble segments is different from that typical of French.

The second preamble is followed by the first rheme: 'mul oli liikkakamat mukan koulussa' ('I had brought my gym stuff to school', line 04 ). In accordance with the theory of Morel and Danon-Boileau (1998: 45), the rheme expresses here a singularized positioning of the speaker concerning the object of discourse that has been introduced in the preamble. In light of these data, the general structure of the Finnish rheme also seems similar to the French one: 'pronoun + verb $+\mathrm{X}$ ' (cf. Section 3). In this example (line 04 ), the rheme is a possessive structure which starts with the habitive adverbial ' $m u$ ' (shortened from 'minulla', the adessive form of the ISG personal pronoun 'minä', 'I'), which refers to 'minäpösilö' ('me dummy', line $0_{3}$ ), the subject of the last preamble. Thus, in addition to constituting the dissociated modus of the preamble, 'minäpösilö' can be considered to act as the disjointed lexical support as well.

In light of these data, it also seems like the Finnish rheme - unlike the preambles - does not normally include any continuation-implicative syntactic features. Indeed, the first preamble (line or) is continuation-implicative because of the interrogative form of the utterance ('guess what me dummy I did'), and the second preamble (line o3) ends with the conjunction ' $k u$ ' (shortened from ' $k u n$ ', 'when') which clearly indicates incompleteness. The utterance ' $m u l$ oli liikkakamat mukan koulussa' ('I had brought my gym stuff to school', line 04), in turn, brings a syntactic completion to the whole consisting of these three utterances (preamble I, preamble $2+$ rheme I). The final PR carried by the rheme unifies the preceding constituents and marks the whole they make up as a preamble for what will follow (Morel \& Danon-Boileau, 1998: 23).

Immediately after the production of the utterance carrying the final PR, the interlocutor ('Heidi') marks the reception of what has been said by the enunciative particle ' $\mathrm{mm}$ ' (line o5). This seems natural in light of the iconic uses of a PR in discourse mentioned by Morel and Danon-Boileau (1998: 12-16): according to the authors, calling the attention of the interlocutor and turning towards him constitute iconic uses of a PR. 
A new preamble (preamble 4) immediately follows the reaction (' $\mathrm{mm}$ ') of the interlocutor. This preamble starts with the discursive ligature 'sit' (shortened from 'sitten', 'then', line 06), followed by a framework segment, 'mul oli siin afrikkakaupan kassis' ('I had in that Africa shop's bag', line o6). The structure of this preamble could be compared to that of the existential presentative structure ['il y a $Z$ ], which is one of the two typical disjointed lexical support structures in French (Morel \& Danon-Boileau, 1998: 4I-42). Indeed, according to Savolainen (200I), Finnish possessive structures are reminiscent of Finnish existential structures because they both start with an adverbial modifier, the predicate is in the third person, the word order is inverted and the subject can be in the partitive case ${ }^{21}$. The other typical structure is the pronominal replacement of the supporting element $(\mathrm{Z})$ in the rheme. The disjointed lexical support is the last preamble segment before the rheme, and these two different structures anticipate in opposite ways on the relation between disjointed lexical support and rheme: the existential presentative associates the supporting element to a vast paradigmatic class of potential predicates, whereas the pronominal replacement indicates that the supporting element can be associated to only one predicate.

In the case of the utterance 'mul oli siin afrikkakaupan kassis' ('I had in that Africa shop's bag', line o6), the framework segment also includes the disjointed lexical support, 'siin afrikkakaupan kassis' ('in that Africa shop's bag'), to which the speaker refers with the adverb 'siel' (shortened from 'siellä, 'there', line o7) in the rheme that will follow. This type of existential-like possessive structure presents also in Finnish the relation between disjointed lexical support and rheme as one that anticipates the association of the supporting element $(Z)$ with a vast paradigmatic class of potential predicates (cf. Example [A] in appendix).

Concerning the pronominal replacement structure of the disjointed lexical support, the previous rheme (recategorised as a preamble) is an illustration of it (lines 03-04): the possessive structure constituting the rheme (line 04) starts with the habitive adverbial ' $m u l$ ' (shortened from 'minulla', adessive form of the ISG personal pronoun 'minä, 'I', referring to the disjointed lexical supporting element 'minäpösilö, 'me dummy', line $0_{3}$ ). Like in French, in Finnish, this type of structure anticipates associating the supporting element $(\mathrm{Z})$ with only one predicate (cf. Example $[\mathrm{B}]$ in appendix).

The utterance constituting the fourth preamble 'sit mul oli siin afrikkakaupan kassis' ('then I had in that Africa shop's bag', line o6) is obviously syntactically incomplete, because it is a possessive structure, the subject of which is still missing. This incompleteness naturally implicates continuity. The subject ('kaikki', 'everything') is given in the possessive structure constituting the second rheme (line 07), 'mul oli siel sit kaikki' ('I had everything there'). Thus, here too, the rheme utterance brings syntactic completion to the whole constituted by the preamble and the rheme, and it particularizes the contents presented in the preamble.

21. The Finnish subject is most often in the nominative case. 
The second oral paragraph starts with the discursive ligature 'ja sitteb' ('and then', line o8). The ligature is followed by two consecutive framework segments: 'näist kaapeist ei oo mitää muut bar: haittaa' ('these cupboards cause nothing but harm', lines 08-09) and ' $m(b) \ddot{a} j(b) \ddot{a t i n}$ kaappii sen pussukan' ('I left that bag in the cupboard', line Io). Syntactically, these framework utterances are not incomplete, but their status as preamble segments is clearly indicated by the overall structure of the second oral paragraph. Firstly, the discursive ligature ' $j a$ sitteb' ('and then', line 08 ) indicates that a new paragraph is about to start and thus anticipates the occurrence of at least one framework segment before the production of the rheme. Secondly, the whole consisting of the preamble segments (lines o8-ı) would not be complete without the particularization brought by the rheme: 'siel on nyt kaikki mun dödöt ja meikit ja' ('there are now all my deodorants and make-ups and', line II).

Indeed, the singularized positioning, or the "point", expressed in the third rheme (line II) unites the whole formed by the rheme utterrance and the preceding preamble segments. The first framework, 'näist kaapeist ei oo mitää muut bar: baittaa' ('these cupboards cause nothing but harm', lines $08-09$ ) is an existential structure that introduces the notion of the cupboard ('kaapeist', line o9), which becomes an argument of the verb 'jättää ('to leave', line ro) in the second framework. The second framework also includes a disjointed lexical supporting element: 'sen pussukan' ('that bag', line Io), which, in turn, is replaced by the adverb 'siel' (shortened from 'siellä', 'there', line II) in the rheme. Thus, there is a kind of "approaching process" (Morel \& Danon-Boileau 1998: 37) happening here: the first framework introduces a notion, the second framework specifies the predicative field of this notion and the disjointed lexical support (included in the second framework) presents an element that becomes an argument in the rheme.

The third rheme is an existential structure ('siel on nyt kaikki mun dödöt ja meikit ja', 'there are now all my deodorants and make-ups and', line II). Thus, all rheme utterances of this extract are either existential-like possessive structures

Contrary to the first rheme, the second one does not end with a rising pitch. Thus, it is not recategorised as a preamble for what will follow. The oral paragraph does not, however, end immediately after the rheme because the rheme is still followed by a group of words ('mun dödö barja meikkipussi', 'my deodorant brush toilet bag', lines 07-08) listing some of the things that are included in 'kaikki' ('everything', line 07 ), the subject of the rheme. This sequence constitutes the last constituent of the oral paragraph: the post-rheme. According to Morel and Danon-Boileau (1998: 28-32), when the post-rheme occurs, it can be either I) a sequence indicating epistemic modality or point of view, or 2) a nominal argument which is co-referent with a pronoun of the rheme. In this example, the post-rheme falls within the second-mentioned category: it is a nominal argument which is co-referent with the indefinite pronoun 'kaikki' ('everything'). The post-rheme includes here nine syllables, which is one more than the maximum number of syllables of a post-rheme in French (Morel \& Danon-Boileau, 1998: 29). 
(rheme I, rheme 2$)^{22}$ or existential structures (rheme 3). The third rheme ends with the word ' $j a$ ' ('and'), which is a typical coordinating conjunction in Finnish and which could for this reason easily be considered as a continuation-implicative syntactic feature. However, in this particular case, the word ' $j a$ ' rather acts as a discursive particle that implicates inexhaustibleness of the list ("kaikki mun dödöt ja meikit ja', 'all my deodorants and make-ups and') describing the contents of the bag.

I will now present three other examples. However, for lack of space, they will only be presented with the help of transcriptions and tables classifying the different constituents and sub-constituents of each oral paragraph. Example [3] presents a face-to-face conversation in which two girls, Heidi and Sanna, talk about dogs. Heidi tells Sanna a funny detail about a social event she had been participating in in Italy: in Heidi's story a young woman had thrown a lipstick tube to her dog instead of a stick.

[3] or Heidi: \#Ku<\# Mähän kerroin joskus sulle et Italias

$$
\text { when I told once to you that in Italy }
$$

Heidi: Like I told you once that in Italy

$\begin{array}{lll}\text { O2 tai jossai } & \mathrm{ku}<. \mathrm{hh} \\ \text { or } & \text { somewhere } & \text { when }\end{array}$

o3 (.) @Me mentiin semmoseen paik- teatteriin ja we went to this pla- theatre and

O4 vietii autot (semmoseen) autotalliin ni siel took the cars (to this) garage so there

o5 oli semmonen tyt- tai semmonen nainen ni<@ was this gi- or this woman so

o6 $\rightarrow$ (siin meiän) talost mil oli se koera? (in that our) house-ELA who had that dog from our bouse who bad that dog

$07($.

o8 Heidi: .hh@£Ni sit just vuoroelle heitetää keppii. £@ so then like by turn one throws a stick Heidi: so then like when taking turns to throw a stick

o9 (.) @Ni se heitti huulirasvapuikkoo so she threw a lipstick tube

IO [ja hakirsiä@ and fetched it

22. The first rheme in Example [3] is also an existential-like possessive structure. 
II Sanna: [hhhhah hah hah hah .hhh iha:na.=

(laughing) cute

(Routarinne, 2003: I84) (5.Io) [pojat.kas 'boys.ftf] KOIRAT'the dogs'

\begin{tabular}{|c|c|c|}
\hline $\begin{array}{l}\text { Constituent } \\
\text { of the oral } \\
\text { paragraph }\end{array}$ & Sub-constituent & $\begin{array}{l}\text { Speaker and speech segment } \\
\text { (+ English translation) }\end{array}$ \\
\hline \multirow[t]{3}{*}{ Preamble I } & Discursive ligature & HEIDI: Ku ('Like') ${ }^{23}$ \\
\hline & $\begin{array}{l}\text { Point of view }+ \text { Dissociated } \\
\text { modus }\left(- \text { hän }^{24}\right)\end{array}$ & $\begin{array}{l}\text { Mähän kerroin joskus sulle } \\
\text { ('As I told you once') }\end{array}$ \\
\hline & Framework I & $\begin{array}{l}\text { et Italias tai jossai ku } \\
\text { ('that in Italy or somewhere when') }\end{array}$ \\
\hline \multirow[t]{2}{*}{ Preamble 2} & $\begin{array}{l}\text { Framework } 2+\text { Dissociated } \\
\text { modus (semmoseen }{ }^{25} \text {, 'to this') }\end{array}$ & $\begin{array}{l}\text { Me mentiin semmoseen paik- } \\
\text { teatteriin ja vietiin autot } \\
\text { (semmoseen) autotalliin ni } \\
\text { ('we went to this pla- theatre and took } \\
\text { the cars (to this) garage so') }\end{array}$ \\
\hline & $\begin{array}{l}\text { Framework } 3 \text { + Dissociated modus } \\
(\text { semmonen, 'this') + Disjointed } \\
\text { lexical support (semmonen tyt- tai } \\
\text { semmonen nainen, 'this gi- or this } \\
\text { woman') }\end{array}$ & $\begin{array}{l}\text { siel oli semmonen tyt- tai semmonen } \\
\text { nainen ni (siin meiän) talost } \\
\text { ('there was this gi- or this woman so } \\
\text { (from our) bouse') }\end{array}$ \\
\hline $\begin{array}{l}\text { Rheme I } \rightarrow \\
\text { Preamble } 3\end{array}$ & $\begin{array}{l}\text { Framework } 4 \\
\text { (Recategorization of the rheme) }\end{array}$ & mil oli se koera? ('who had that dog') \\
\hline \multirow[t]{2}{*}{ Preamble 4} & \begin{tabular}{|l} 
Discursive ligature \\
(ni sit just, 'so then like')
\end{tabular} & \multirow{2}{*}{$\begin{array}{l}\text { Ni sit just vuoroelle heitetää keppii } \\
\text { ('so then like when throwing a } \\
\text { stick turn and turn about') }\end{array}$} \\
\hline & $\begin{array}{l}\text { Framework } 5 \text { (vuoroelle heitetää }{ }^{26} \\
\text { keppii, 'throwing a stick turn } \\
\text { and turn about') }\end{array}$ & \\
\hline Rheme 2 & & $\begin{array}{l}\text { Ni se heitti huulirasva-puikkoo ja } \\
\text { haki sitä ('so she tbrew a } \\
\text { lipstick tube and fetched it') }\end{array}$ \\
\hline $\begin{array}{l}\text { (Reaction } \\
\text { of the } \\
\text { interlocutor) }\end{array}$ & & $\begin{array}{l}\text { SANNA: hhhhah hah hah hah .hhh } \\
\text { iha:na ([laughing] 'cute') }\end{array}$ \\
\hline
\end{tabular}

Table 1. Classification of the constituents and sub-constituents of the oral paragraph occurring in Example [3]

23. The literal translation of the conjunction ' $k u n$ ' (shortened ' $k u$ ') would be 'when'.

24. The Finnish clitic particle '- $h A n$ ' is typically used to indicate that what is being said is supposed to belong to the field of common knowledge of the participants (Hakulinen et al., 2004: 797).

25. The word 'semmonen' is a frequently used spoken language variant of the pro-adjective 'sellainen' ('this' or 'a kind of). It is used here to implicate certain indefiniteness of the headword it refers to. For Finnish pro-adjectives, cf. Hakulinen et al., 2004: 705.

26. 'Heitetää is a spoken language variant of the present tense passive 'beitetään' ('one throws'). The one-person Finnish passive refers to a general plural human subject argument (Hakulinen et al., 2004: I26I-I266). 
Example [4] has been drawn from a telephone conversation. The girls, Jenni and Laura, are sharing their latest news and Laura tells Jenni about the way she had sprained her ankle ${ }^{27}$.

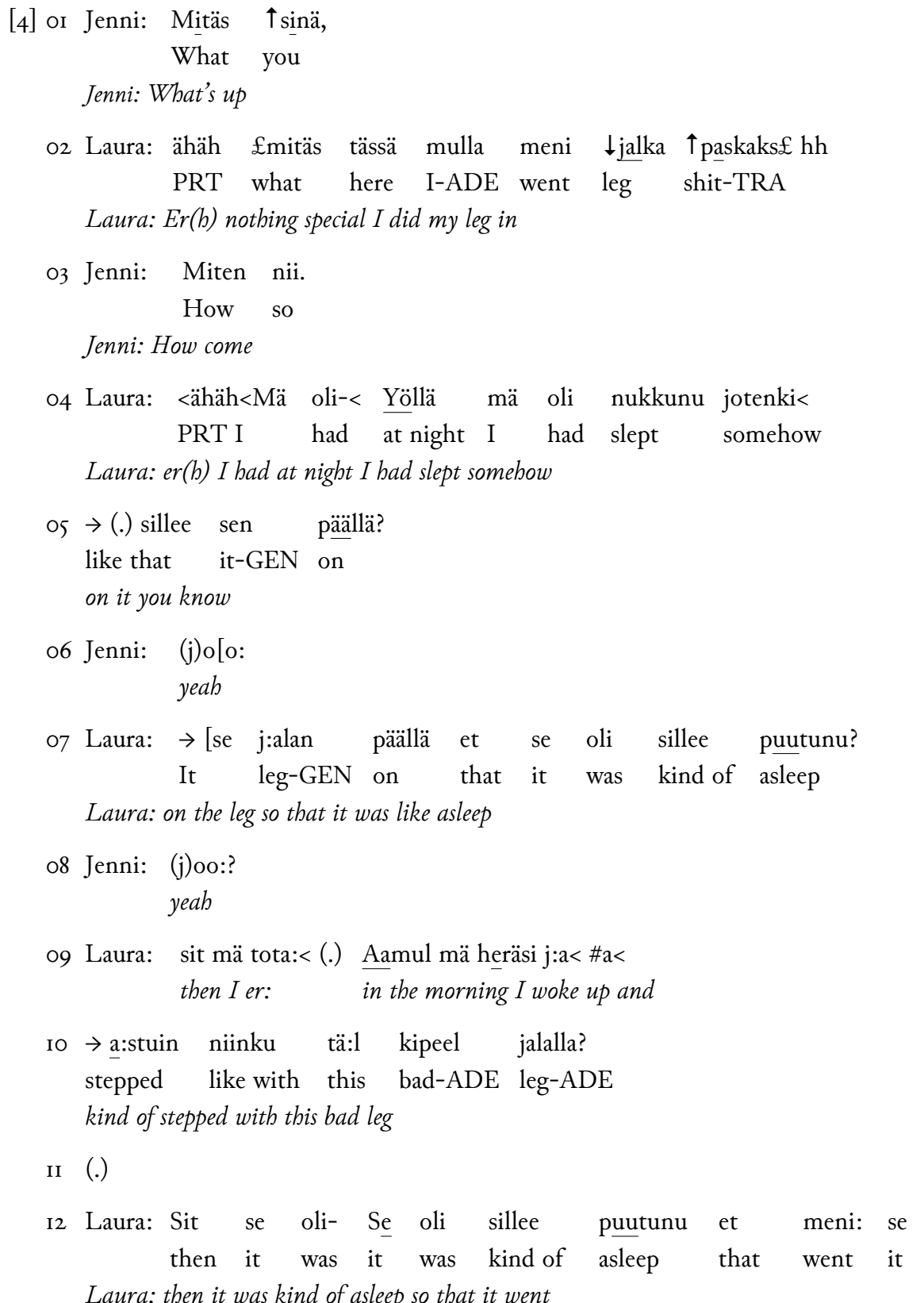

27. A pitch trace of the segment 'yöllä mä olin nukkunu jotenki sillee sen päällä' (lines 04-o5) is given in Ogden and Routarinne (2005: 164). 
I3 niinku @kruts@ vaa kuuli sil[lee niinku et(- -)] like crack only heard kind of like that like crack one could just hear a sound like that

I4 Jenni: [.mt Hyi: kauhee.]

Yuck terrible

(Routarinne, 2003: 197) (5.13) [nilkka.pub 'ankle.tel'] NILKKA 'the ankle'

\begin{tabular}{|c|c|c|}
\hline $\begin{array}{l}\text { Constituent of } \\
\text { the oral paragraph }\end{array}$ & Sub-constituent & $\begin{array}{l}\text { Speaker and speech segment } \\
\text { (+ English translation) }\end{array}$ \\
\hline $\begin{array}{l}\text { PARAGRAPH } \mathrm{i}: \\
\text { (Opening } \\
\text { question) }\end{array}$ & & JENNI: Mitäs sinä, ('What’s up’) \\
\hline \multirow[t]{2}{*}{ Preamble I } & Enunciative ligature & LAURA: Ähäh ('Er(b)') \\
\hline & Dissociated modus & mitäs tässä ('notbing special') \\
\hline Rheme I & & $\begin{array}{l}\text { mulla meni jalka paskaks }{ }^{28} \\
\text { ('I did my leg in') }\end{array}$ \\
\hline $\begin{array}{l}\text { PARAGRAPH 2: } \\
\text { (Question) }\end{array}$ & & JENNI: Miten nii. ('How come') \\
\hline \multirow[t]{2}{*}{ Preamble 2} & Enunciative ligature & LAURA: Ähäh (' $\left.E r(b)^{\prime}\right)$ \\
\hline & Framework I & Mä oli ('I had') \\
\hline Preamble 3 & Framework 2 & Yöllä ('at night') \\
\hline $\begin{array}{l}\text { Rheme } 2 \rightarrow \\
\text { Preamble } 4\end{array}$ & $\begin{array}{l}\text { Framework } 3 \\
\text { (Recategorization of the rheme) }\end{array}$ & $\begin{array}{l}\text { mä oli nukkunu jotenki (.) sillee } \\
\text { sen päällä? ('I bad slept somebow (.) } \\
\text { on it you know') }\end{array}$ \\
\hline $\begin{array}{l}\text { (Minimal } \\
\text { response) }\end{array}$ & & JENNI: (j)o[o: ('yeab’) \\
\hline Preamble 5 & Disjointed lexical support & $\begin{array}{l}\text { LAURA: [se j:alan päällä } \\
\text { ('on the leg') }\end{array}$ \\
\hline $\begin{array}{l}\text { Rheme } 3 \rightarrow \\
\text { Preamble } 6\end{array}$ & $\begin{array}{l}\text { Framework } 4 \text { (Recategorization of } \\
\text { the rheme) }\end{array}$ & $\begin{array}{l}\text { et se oli sillee puutunu? } \\
\text { ('so that it was like asleep') }\end{array}$ \\
\hline $\begin{array}{l}\text { (Minimal } \\
\text { response) }\end{array}$ & & JENNI: (j)oo:? ('yeab’) \\
\hline \multirow[t]{3}{*}{ Preamble 7} & Discursive ligature & LAURA: sit ('then') \\
\hline & Framework 5 & mä tota: ${ }^{29}$ ('I er:') \\
\hline & Framework 6 & Aamul ('in the morning') \\
\hline
\end{tabular}

28. The habitive adverbial ' $m u l l a$ ' is used here to identify the person who is experiencing the action indicated by the predicate (Hakulinen et al., 2004: 937).

29. Tota is a typical particle of formulation in Finnish (Hakulinen et al., 2004: 82I-822). 


\begin{tabular}{|l|l|l|}
\hline $\begin{array}{l}\text { Rheme } 4 \rightarrow \\
\text { Preamble } 8\end{array}$ & Framework 7 & $\begin{array}{l}\text { mä heräsi j:a \#a a:stuin niinku täl } \\
\text { kipeel jalalla? ('I woke up and kind } \\
\text { of stepped with this bad leg') }\end{array}$ \\
\hline Preamble 9 & Discursive ligature & Sit ('then') \\
\hline Framework 8 & se oli ('it was') \\
\hline Rheme 5 & $\begin{array}{l}\text { Se oli sillee puutunu et meni: se } \\
\text { niinku kruts vaa kuuli ('it was kind } \\
\text { of asleep that it got like crack one } \\
\text { could hear a sound') }\end{array}$ \\
\hline Post-rheme & \begin{tabular}{l} 
sillee niinku et ('kind of like that') \\
\hline $\begin{array}{l}\text { (Reaction of the } \\
\text { interlocutor) }\end{array}$
\end{tabular} & $\begin{array}{l}\text { JENNI: mt Hyi: kauhee. } \\
\text { ('Yuck terrible') }\end{array}$ \\
\hline
\end{tabular}

Table 2. Classification of the constituents and sub-constituents of the oral paragraphs occurring in Example [4]

The last example has been drawn from a telephone conversation in which Heidi has told her friend that she is her aunt's confidante. From this perspective she has also reported things related to her grandmother, Alli. In this extract Heidi mentions that Alli had been very afraid of something, apparently of a grave illness.

[5] or Heidi: .hhh Niinni nytki se oli- (.) Nyt se kerto joo- (.)

So this time too she had- Now she told yeab-

O2 Siit- (.) et seol (.) Et sei niinku sanonnu .h

That-PAR that se had That she had not PRT said

About the thing that she bad that she didn't say

$03 \rightarrow$ se $<$ Alli et sii- et sitä pelottaa? (.)

that Alli that sh- that she was afraid

04 Heidi: .hhh mut sitä pelo:tti kauheest=

but she was very afraid

(Routarinne, 2003: 283) (7.30) [seura.pub 'society.tel'] USKOTTU'the confidante'

\begin{tabular}{|l|l|l|}
\hline $\begin{array}{l}\text { Constituent of } \\
\text { the oral paragraph }\end{array}$ & Sub-constituent & $\begin{array}{l}\text { Speaker and speech segment } \\
\text { + English translation) }\end{array}$ \\
\hline Preamble I & Discursive ligature & HEIDI: Niinni 'So' \\
\hline & $\begin{array}{l}\text { Framework I + Dissociated modus } \\
(-\mathrm{ki})^{30}\end{array}$ & nytki se oli- 'this time too she had-' \\
\hline
\end{tabular}

30. The clitic particle - $k$ in (often shortened ' $-k i$ in spontaneous speech) is used to bring a certain element of the utterance into focus (Hakulinen et al., 2004: 806-807), and it often carries more or less the meaning of 'also'. Here it emphasises the word nyt ('now' $\rightarrow \sim$ 'now also'); the fact that this was not the first time the speaker's aunt told her something confidential. 


\begin{tabular}{|l|l|l|}
\hline Preamble 2 & $\begin{array}{l}\text { Framework 2+ Point of view (se } \\
\text { kerto, 'she told') }\end{array}$ & Nyt se kerto 'Now she told' \\
\cline { 2 - 3 } & + Enunciative ligature & joo- 'yeab-' \\
\hline Preamble 3 & Framework 3 & $\begin{array}{l}\text { Siit- (.) et seol 'About the thing that } \\
\text { she bad' }\end{array}$ \\
\hline Preamble 4 & Discursive ligature & Et 'That' \\
\cline { 2 - 3 } & Framework 4 & sei niinku sanonnu 'she didn't say' \\
\cline { 2 - 3 } & Disjointed lexical support & se Alli 'that Alli' \\
\hline $\begin{array}{l}\text { Rheme I } \rightarrow \\
\text { Preambule } 5\end{array}$ & $\begin{array}{l}\text { Framework 5 (Recategorization of } \\
\text { the rheme) }\end{array}$ & $\begin{array}{l}\text { et sii- et sitä pelottaa? 'that sh- that } \\
\text { she was afraid' }\end{array}$ \\
\hline Rheme 2 & & $\begin{array}{l}\text {.hhh mut sitä pelo:tti kauheest= } \\
\text { 'but she was very afraid' }\end{array}$ \\
\hline
\end{tabular}

Table 3. Classification of the constituents and sub-constituents of the oral paragraphs occurring in Example [5]

\section{Conclusion}

Despite the fact that French and Finnish are typologically distant languages and basically characterised by very different intonation systems, some remarkable similarities can be found concerning the use of utterance-final PRs in discourse. Indeed, both the findings of Routarinne (2003) concerning Finnish and those of Morel and Danon-Boileau (1998) concerning French suggest that an utterance-final PR typically I) indicates continuity, 2) calls the interlocutor's attention, 3) is used to focus the interlocutor's attention, 4) constitutes a sign of turning towards the interlocutor, and 5) orients the recipient with regard to what will follow. These similar features were found simply by comparing the results of the studies of Routarinne (2003) and Morel and Danon-Boileau (1998). The original contribution of this paper concerns the phenomenon consisting of the recategorization of the rheme with the help of an utterance-final PR: indeed, applying the theory of Morel and Danon-Boileau (1998) to the data of Routarinne (2003) shows that the Finnish utterances carrying a final $\mathrm{PR}$ actually constitute rheme segments that are being recategorised as preambles for what will follow.

The similarity does not, however, concern other positions: the French preambles always carry a final PR (Morel \& Danon-Boileau, 1998), whereas - according to this study - the Finnish preambles do not. Thus, whereas the oral paragraphs of French always include several utterance-final PRs, the only utterance-final PRs occurring in the Finnish data are those carried by the recategorised rheme segments. As the final PR occurs in the Finnish data only as a recategorization means and not as a standard element of a certain constituent of the oral paragraph, it remains a marked feature in the Finnish data. 
As far as the structure of the oral paragraph is concerned, the findings presented in this paper suggest that the Finnish preamble is much more condensed than the French preamble. According to Morel and Danon-Boileau (1998: 37), the French preamble is typically very long and even a bit heavy. However, as in French, if one or several of the preamble constituents do not occur, the functions typically carried by them are taken over by the other constituents. Indeed, in the Finnish data, one preamble constituent typically carries several functions. In other words, whereas the French preamble constituents typically occur one after another, in the Finnish data, the preamble consists of overlapping segments. For instance, the elements constituting the framework often also carry the functions of several other preamble constituents such as the point of view, the dissociated modus and the disjointed lexical support. Consequently, the Finnish preamble is generally much shorter than the French preamble. Unlike in French, the preambles do not carry a final pitch rise in the Finnish data. On the other hand, instead of using prosodic means for indicating the continuation of the oral paragraph, the preambles of the Finnish data normally include continuation-implicative syntactic features. This highlights the complementarity and the non-redundancy of different levels of marks of cohesion in the structuration of discourse (Morel \& Danon-Boileau, 1998).

In light of these data, the general structure of the Finnish rheme seems similar to the French one: 'pronoun + verb + X' ('X' being a complementary sequence, the nature of which is variable). As in French, it expresses a singularized positioning of the speaker with regard to what has been presented in the preamble (the "point" where the preamble has been driving at). It also brings syntactic completion to the whole constituted by the preambles and by the rheme. Unlike the preambles, the rheme does not normally include any continuation-implicative syntactic features.

\section{Conventions of transcription used in the French examples}

$\begin{array}{ll}\mathrm{PITCH}^{31} & \\ \mathrm{H}_{1} & \text { lowest pitch level } \\ \mathrm{H}_{4} & \text { highest pitch level } \\ \mathrm{H}_{2} \text { and } \mathrm{H}_{3} & \text { intermediate pitch levels } \\ \mathrm{H}_{2}, 5 & \text { pitch level situated between the levels } \mathrm{H}_{2} \text { and } \mathrm{H}_{3} \\ \mathrm{H}_{2}+ & \text { pitch level slightly superior to the level } \mathrm{H}_{2} \\ \mathrm{H}_{2}- & \text { pitch level slightly inferior to the level } \mathrm{H}_{2} \\ \text { low range } & \text { pitch range situated between } \mathrm{H}_{\mathrm{I}} \text { and } \mathrm{H}_{2,5}\end{array}$

31. Different pitch levels $\left(\mathrm{H}_{\mathrm{I}}-\mathrm{H}_{4}\right)$ have been determined with regard to the range of variation of each speaker. For male speakers, the range of variation is generally between 50 and $300 \mathrm{~Hz}$ and for female speakers between 150 and $400 \mathrm{~Hz}$. 


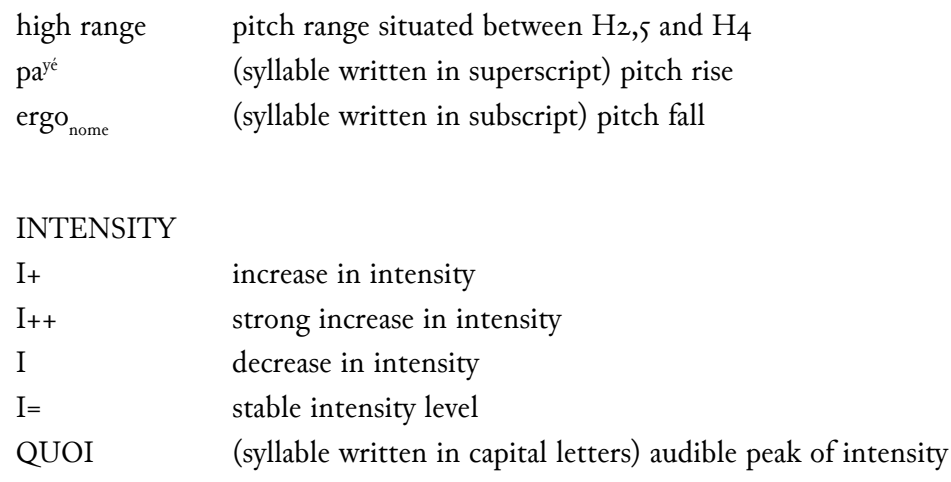

\title{
OTHER SIGNS
}

\{40\} duration of a pause in centiseconds

\{ \} pause the duration of which has not been measured

cs centisecond

(h) audible breathing

$\mathrm{x}$ / $\mathrm{x}::$ lengthening of a syllable

e / e::: 'euh' of hesitation

/ glottal stop causing a sudden interruption of the sound production

${ }^{\circ} \mathrm{xxx}^{\circ} \quad$ interpolated clause

$\S \quad$ speech overlap 32

\section{Conventions of transcription used in the Finnish examples}

PITCH
Arvaa mitä33
$?$
?
$\cdot$
$\uparrow$
$\downarrow$

\begin{abstract}
beginning of a new declination unit
strongly rising pitch at the end of a prosodic unit

slightly rising pitch at the end of a prosodic unit

strongly falling pitch at the end of a prosodic unit

flat or slightly falling pitch at the end of a prosodic unit

the following word is produced on a higher pitch level than surrounding speech ${ }^{34}$

the following word is produced on a lower pitch level than surrounding speech
\end{abstract}

32. $\S m m \S$ is a sign of approval of the interlocutor.

33. A capital letter in the beginning of an utterance.

34. The same notation has been used when there is some kind of complement that continues the turn after the end of a TCU and a TRP. TCU (turn-constructional unit) and TRP (transition-relevance place) are basic notions of CA (Sacks, Schegloff \& Jefferson, I974). TCU is a syntactic and a prosodic unit of speech which could in principle constitute an entire turn. The end of a TCU creates a TRP which, in turn, makes the transition of the turn relevant. The transition does not, however, occur necessarily at all TRPs. 
Ke $\uparrow$ sätöistä ja $\uparrow$ segment produced on a higher or on a lower $(\downarrow)$ pitch level than surrounding speech

heti stress

OVERLAPS AND PAUSES

[ beginning of an overlap of speech

] end of an overlap of speech

(. ) micropause (duration 0.2 seconds or less)

(o.4) duration of a pause in tenths of a second

$=\quad$ two utterances are produced one after another without a perceivable pause

SPEECH RATE

$>\quad \quad$ word(s) produced more rapidly than surrounding speech

$\quad \quad \quad$ word(s) produced slower than surrounding speech

$<\quad$ glottal stop or another stop in the vocal tract that keeps the turn reserved

e::i lengthening of a sound

$\circ \quad$ segment produced more quietly than surrounding speech

AHA segment produced louder than surrounding speech

\section{BREATHINGS}

.hh inhalation

hh exhalation

.joo word produced with an inhalation

.mth smack of lips at the beginning of an inhalation

\section{LAUGHTER}

he he laughter

$\mathrm{s}(\mathrm{h})$ ana $\quad$ word associated with an exhalation (often due to laughter)

$£ £ \quad$ word or segment produced with a smile

\section{OTHER SIGNS}

$\rightarrow \quad$ relevant line in the extract

\# \# creaky voice

@@ change of quality of voice

si- $\quad$ interrupted word

s'tä elision of a vowel

(tai) unclear segment or speaker

( - ) unintelligible word

(- -) several unintelligible words

((crunching)) explanation given by the transcriber

Maija proper nouns are written with a capital letter 


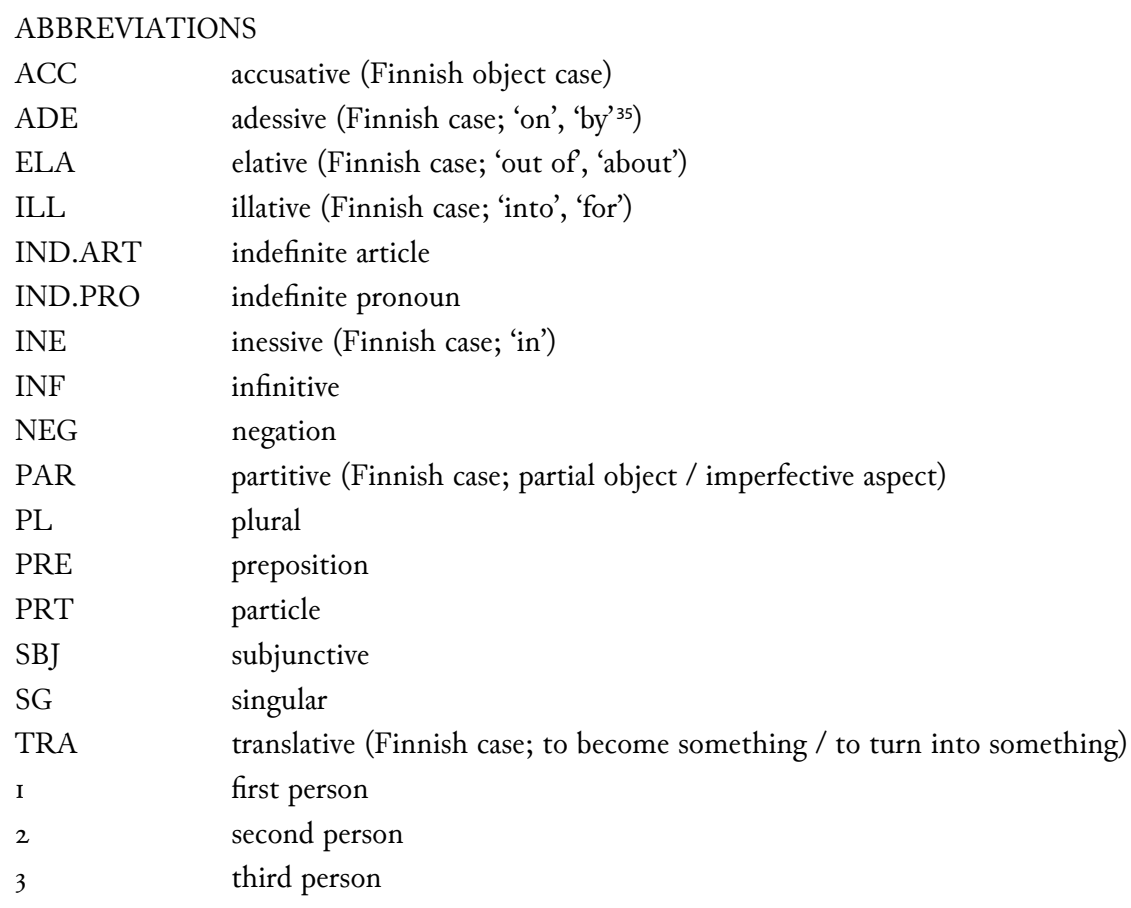

\section{References}

Bö̈, L.-J. \& ConTını, M. I975. Étude de la phrase interrogative en français. Bulletin de l'Institut de Phonétique de Grenoble 4: 85-102.

Delattre, P. 1966. Les dix intonations de base du français. French Review 40 (I): I-I4.

Di Cristo, A. I998. Intonation in French. In D. Hirst \& A. Di CRISTo (eds), Intonation Systems: A Survey of Twenty Languages. Cambridge: Cambridge University Press: 195-218.

Ducrot, O. 1972. Dire et ne pas dire. Paris: Hermann.

FónAGy, I. 197I. Le signe conventionnel motivé. La Linguistique 7: 55-80.

FónAgY, I. \& FónAgY, J. 1983. L'intonation et l'organisation du discours. BSLP 78 (I): I6I-209.

Grevisse, M. \& Goosse, A. 2008. Le bon usage. Grammaire française. Brussels - Paris: De Boeck - Duculot [I $4^{\text {th }}$ edition].

HaKulinen, A. et al. 2004. Iso suomen kielioppi (The big grammar of Finnish). Helsinki: SKS.

HAKULINEN, L. I979. Suomen kielen rakenne ja kebitys (The structure and the development of Finnish). Helsinki: Otava [4 ${ }^{\text {th }}$ revised edition].

35. The prepositions given in parentheses indicate the approximate meaning of the cases. The list is naturally far from being exhaustive. For more information about Finnish grammar, cf. for example Hakulinen et al. (2004). 
Hirvonen, P. 1970. Finnish and English Communicative Intonation. Turku: The Phonetics Department of the University of Turku.

IIVOnEN, A. 1978. Is there interrogative intonation in Finnish? In E. GÅRDING, G. BRUCE \& R. Bannert (eds), Nordic Prosody. Papers from a Symposium. Lund: Lund University, Department of Linguistics: $43-53$.

Irvonen, A. 1998. Intonation in Finnish. In D. Hirst \& A. Di CRIsto (eds), Intonation Systems: A Survey of Twenty Languages. Cambridge: Cambridge University Press: 311-327.

Iivonen, A. 200I. Intonation in Finnish questions. In W. Van Dommelen \& T. Fretheim (eds), Nordic Prosody. Proceedings of the VIII't Conference, Trondheim 200o. Frankfurt am Main: Peter Lang.

Irvonen, A. et al. 1987. Pubeen intonaatio (The intonation of speech). Helsinki: Gaudeamus.

Kallioinen, V. 1968. Suomen kysymyslauseen intonaatiosta (About the intonation of the Finnish interrogative clause). Virittäjä 72: 35-54.

LABOv, W. 1972. Language in the Inner City. Philadelphia: University of Pennsylvania Press.

LÉON, P.R. 1992. Phonétisme et prononciations du français. Paris: Nathan [ $4^{\text {th }}$ edition].

LÉON, P.R. \& BHATT, P. I987. Les Structures prosodiques du questionnement radiophonique. Études de linguistique appliquée 66: 88-105.

LyYTiKÄInEN, E. I995. Naisten sävel (Women's tone). In E. LyYTIKÄINEN (ed.), Bikinirajaus - näkökulmia kieleen. Helsinki: SKS: 54-55.

Мӓ̈̈ттё, T. 1973. Rovaniemen seudun nousevasta intonaatiosta (About the rising intonation of the region of Rovaniemi). Oulun yliopiston fonetiikan laitoksen monisteita 3: 46-49.

Malmberg, B. 1976. Phonétique française. Lund: LiberLäromedel.

Mertens, P. 1990. L'intonation. In C. Blanche-Benveniste et al. (eds), Le français parlé. Études grammaticales. Paris: CNRS Éditions: 159-176.

Morel, M.-A. 2003. Phrase? Énoncé? Paragraphe? Hyperparagraphe? Quelles unités intonatives et discursives pour le dialogue oral en français? L'Information Grammaticale 98: 39-47.

Morel, M.-A. \& Danon-Boileau, L. 1998. Grammaire de l'intonation. L'exemple du français. Paris - Gap: Ophrys.

Ogden, R. \& Routarinne, S. 2005. The communicative functions of final rises in Finnish intonation. Phonetica 62: I60-175. Available online at: http://content.karger.com/ ProdukteDB/produkte.asp?doi=90096.

Riegel, M., Pellat, J.-C. \& Rioul, R. 1994. Grammaire méthodique du française. Paris: PUF.

Rossi, M. 198I. Continuation et question. In M. Rossi et al. (eds), L'intonation: de l'acoustique à la sémantique. Paris: Klincksieck.

Rossi, M. 1999. L'intonation, le système du français: description et modélisation. Paris - Gap: Ophrys.

Routarinne, S. 2003. Tytöt äänessä. Parenteesit ja nouseva sävelkulku kertojan vuorovaikutuskeinoina (Girls talking. Parentheses and rising intonation as narrator's interactional devices). Helsinki: SKS. 
SACKs, H., Schegloff, E. \& JefFerson, G. 1974. A simplest systematics for the organization of turn-taking for conversation. Language 50: 696-735.

SAVolainen, E. 20oI. Verkkokielioppi. Suomen kielen äänne-, muoto- ja lauseoppia (Online grammar. Finnish phonology, morphology and syntax). Helsinki: Finn Lectura. Available online at: http://www.finnlectura.fi/verkkosuomi/.

WAGNER, R.-L. 1980. Essais de linguistique française. Paris: Nathan.

WANDE, E. 1982. Ruotsin Tornionlaakson suomi ja sen ominaispiirteet (The Finnish language and its characteristic features in Swedish Tornionlaakso). Suomen kieli Ruotsissa-Suomen kieli Tornionlaaksossa. Stockholm: Finn-Kirja: 39-7I.

Wunderli, P. 1984. L'intonation des questions sans marque segmentale. Travaux de Linguistique et de Littérature 22 (I): 203-250.

\section{Appendix}

Example [A]: Existential-like possessive structure as a disjointed lexical support in Finnish. $(Z$ = supporting element $)$

$\mathrm{Z}=$ 'koira' ('dog')

'Minulla oli koira' ('I had a dog')

'jokaoli söpö' ('that was cute')

(+) 'jokaosasi juosta kovaa' ('that could run fast')

(+) 'jokakuoli nuorena' ('that died young')

(+) 'joka baukkui naapureita' ('that barked at neighbours')

Etc.

Example [B]: Pronominal replacement structure as a disjointed lexical support in Finnish. ( $\mathrm{Z}=$ supporting element)

$\mathrm{Z}=$ 'koirani' ('my dog'), pronominal replacement = 'se' ('it')

'Koirani' ('my dog')

'se oli söpö' ('it was cute')

I 'se osasi juosta kovaa' ('it could run fast')

/ 'se kuoli nuorena' ('it died young')

I 'se baukkui naapureita' ('it barked at neighbours')

Etc. 